\title{
VARIABEL DAN SKALA PENGUKURAN STATISTIK
}

\author{
Nama : Nilda Miftahul Janna \\ NIM : 18210047
}

Email : nildamiftahuljanna@gmail.com

\begin{abstract}
ABSTRAK
Setelah merumuskan rumusan masalah, mengukur variabel dalam kerangka teori merupakan bagian integral dari penelitian yang merupakan aspek penting dari desain penelitian. Objek yang secara fisik dapat diukur dengan beberapa instrumen yang dikaliborasi tidak menimbulkan masalah pengukuran. Skala pengukuran digunakan untuk menentukan panjang pendeknya interval yang ada dalam satuan alat ukur. Dengan menggunakan skala pengukuran, maka alat ukur yang digunakan akan menghasilkan data kuantitatif. Statistik deskriptif digunakan untuk menganalisis data dengan cara mendeskripsikan atau menggambarkan data yang telah terkumpul sebagaimana adanya tanpa bermaksud membuat kesimpulan yang berlaku umum atau general. Statistik nonparametrik merupakan kumpulan metode untuk analisis data yang menawarkan sebuah pendekatan yang berbeda dengan cara-cara pengambilan keputusan lainnya. Pendekatan ini tidak menekankan kepada asumsi-asumsi sebagaimana terdapat statistic parametrik, seperti distribusi sampel dari parameter populasi dianggap normal. Uji hipotesis lebih mengasumsikan bahwa distribusi sampel dianggap tidak normal, biasanya untuk ukuran sampel relatif kecil.
\end{abstract}

\section{Kata Kunci : Variabel, Pengukuran, Deskriptif, Inferensial, Parametrik,}

\section{PENDAHULUAN}

Secara teoritis variabel penelitian juga dapat diartikan sebagai suatu atribut atau sifat nilai dari orang, obyek atau kegiatan yang mempunyai variasi tertentu yang ditetapkan oleh peneliti untuk dipelajari dan kemudian ditarik kesimpulannya. Variabel ini menjadi sangat penting karena tidak mungkin peneliti melakukan penelitian tanpa adanya variabel. Namun terkadang banyak hal juga yang menyebabkan kita lupa mengenai apa dan seperti apa variabel serta apa saja jenis variabel dalam penelitian itu. Banyak hal yang menjadi pertanyaan dan itulah sebabnya mengupas dengan benar variabel akan menjadi suatu hal yang sangat penting.

Dalam kehidupan sehari-hari di tengah ledakan data, kita tidak dapat melepaskan diri dari data, baik data itu bersifat kuantitatif maupun kualitatif. Kedua data tersebut dapat dianalisis, baik secara kuantitatif maupun kualitatif atau gabungan dari keduanya. Ilmu pengetahuan mengemban tiga tugas penting: menerangkan gejala, meramalkan kejadian, dan mengontrol keadaan. Statistik menyanggupkan dirinya untuk memikul tiga tugas ini. Untuk menerangkan gejala 
disediakan suatu bagian statistik yang disebut statistik deskriptif. Untuk meramalkan dan mengontrol kejadian dipersiapkan suatu bagian statistik yang disebut statististik inferensial. Dan statistik parametrik digunakan untuk menguji hipotesis dan variabel yang terukur dan data yang akan dianalisis menggunakan statistik parametrik harus memenuhi asumsi normalitas. Dan adapun statistik nonparametrik adalah statistik yang tidak mendasarkan pada parameter-parameter statistik.

\section{JENIS VARIABEL DAN SKALA PENGUKURAN}

\section{* Pengertian Variabel Penelitian}

Variabel Penelitian adalah suatu atribut, nilai atau sifat dari objek penelitian (individu atau kegiatan) yang memiliki variasi tertentu antara satu objek dengan objek lainnya. Umumnya variabel penelitian akan ditentukan oleh seorang peneliti untuk dipelajari dan digali Informasi dari objek tertentu yang kemudian ditarik kesimpulannya. Pengertian variabel sendiri menurut Wikipedia adalah objek penelitian, atau apa yang menjadi fokus di dalam suatu penelitian. Secara umum variabel berarti sesuatu yang dapat berubah-ubah, bermacam-macam serta berbeda-beda.

\section{* Jenis-Jenis Variabel Penelitian}

Seperti yang kita ketahui, terdapat berbagai variabel yang dapat mempengaruhi hasil penelitian yang dilakukan. Oleh karena itu, untuk memudahkan dalam penggolongannya variabel dibedakan menjadi berbagai jenis dilihat dari hubungan, sifat, urgensi, skala pengukur dan penampilan waktu pengukuran.

1. Hubungan Antar Variabel

Berdasarkan hubungannya, variabel digolongkan menjadi tiga jenis yaitu variabel bebas, variabel terikat dan variabel kontrol :

- Bebas merupakan jenis variabel yang menjadi penyebab adanya perubahan pada variabel yang lainnya. Contoh dari variabel bebas adalah tegangan seperti pada contoh sebelumnya.

- Terikat merupakan jenis variabel yang dipengaruhi oleh adanya perubahan variabel bebas. Seperti pada contoh kasus sebelumnya, variabel terikatnya adalah kecerahan lampu.

- Kontrol merupakan jenis variabel yang dapat dikendalikan atau dikontrol oleh peneliti. Seperti pada contoh sebelumnya, variabel kontrolnya adalah tegangan karena tegangan dapat diatur sesuai hati. 


\section{Sifat Variabel}

Selain digolongkan berdasarkan hubungannya, variabel juga dapat digolongkan sesuai dengan sifatnya. Pada umumnya, variabel digolongkan menjadi dua sesuai sifatnya yaitu variabel statis dan dinamis.

- Variabel statis merupakan jenis variabel yang tidak dapat berubah-ubah nilai, keadaan atau bahkan karakteristiknya. Pada contoh kasus diatas variabel statis adalah beban atau hambatan lampu itu sendiri.

- Variabel dinamis merupakan kebalikan variabel statis dimana nilai, keadaan atau kerakteristiknya dapat berubah-ubah. Untuk contohnya, pada kasus sebelumnya kita dapat menggolongkan arus dan kecerahan lampu sebagai variabel dinamis.

\section{Urgensi Faktual}

Dilihat dari urgensi faktual, variabel dibedakan menjadi variabel konseptual dan variabel faktual.

- Variabel Konseptual merupakan variabel yang tidak terlihat secara jelas atau sesuai fakta, contohnya adalah motivasi, minat, bakat dan kinerja.

- Variabel Faktual merupakan variabel yang dapat terlihat nyata secara jelas, contohnya adalah tegangan, arus, gen, usia dan lain sebagainya.

\section{Skala Pengukur}

Selain tiga faktor sebelumnya, skala pengukur juga menjadi dasar penggolongan jenis variabel. Menurut tipe skala pengukurnya, variabel dibedakan menjadi empat yaitu : Nominal, Ordinal, Interval dan Rasio.

5. Penampilan Waktu Pengukuran

Berdasarkan waktu pengukurannya, variabel dibedakan menjadi dua jenis yaitu variabel maksimalis dan variabel tipikalis.

- Variabel Maksimalis adalah variabel yang dalam proses pengumpulan data terdapat dorongan kepada responden. Contohnya adalah kerativitas, bakat dan prestasi.

- Variabel Tipikalis merupakan jenis variabel yang dalam proses pengumpulan datanya tidak disertai dorongan kepada responden. Contohnya adalah minat, kepribadian, sikap terhadap hal tertentu.

\section{* Pengertian Skala Pengukuran}

Skala pengukuran adalah sebuah acuan yang digunakan untuk menentukan panjang pendeknya interval yang ada dalam satuan alat ukur. Dengan 
menggunakan skala pengukuran, maka alat ukur yang digunakan akan menghasilkan data kuantitatif. Setelah proses pengukuran yang menghasilkan data kuantitatif yang berupa angka-angka tersebut barulah kemudian ditentukan analisis statistik yang cocok untuk digunakan. Di dalam ilmu statistik, skala pengukuran dibagi menjadi empat, yaitu sebagai berikut :

\section{Skala Nominal}

Skala nominal merupakan skala pengukuran paling sederhana atau tingkatannya paling rendah di dalam suatu penelitian. Skala ini hanya digunakan untuk memberikan kategori saja. Misalnya digunakan untuk memberi label, simbol, lambang, atau nama pada sebuah kategori sehingga akan mempermudah pengelompokan data menurut kategorinya.

Pada skala nominal ini, peneliti akan mengelompokkan objek, baik individu atau pun kelompok kedalam kategori tertentu dan disimbolkan dengan label atau kode tertentu. Kemudian, angka yang diberikan kepada objek hanya memiliki arti sebagai label atau pembeda saja dan bukan untuk menunjukkan adanya tingkatan. Agar lebih paham, berikut ini ciri-ciri dari skala nominal :

- Kategori data bersifat mutually exclusive (setiap objek hanya memiliki satu kategori saja).

- Kategori data tidak memiliki aturan yang logis (bisa sembarang).

\section{Skala Ordinal}

Skala ordinal merupakan skala pengukuran yang sudah menyatakan peringkat antar tingkatan. Jarak atau interval antar tingkatan juga tidak harus sama. Skala ordinal ini memiliki tingkatan yang lebih tinggi daripada skala nominal, karena skala ini tidak hanya menunjukkan kategori saja tetapi juga menunjukkan peringkat. Di dalam skala ordinal, objek atau kategorinya disusun berdasarkan urutan tingkatannya, dari tingkat terendah ke tingkat tertinggi atau sebaliknya, Ciri-ciri dari skala ordinal antara lain :

- Kategori data saling memisah.

- Kategori data ditentukan berdasarkan jumlah karakteristik khusus yang dimilikinya.

- Kategori data dapat disusun sesuai dengan besarnya karakteristik yang dimiliki.

\section{Skala Interval}

Skala Interval merupakan skala pengukuran yang bisas digunakan untuk menyatakan peringkat untuk antar tingkatan. Jarak atau interval antar tingkatan pun sudah jelas, hanya saja tidak memiliki nilai 0 (nol) mutlak. 
Skala interval ini bisa dikatakan berada diatas skala ordinal dan nominal. Besar interval atau jarak satu data dengan data yang lainnya memiliki bobot nilai yang sama. Besar interval ini bisa saja di tambah atau dikurang. Berikut ini adalah ciri-ciri dari skala interval :

- Kategori data memiliki sifat saling memisah.

- Kategori data memiliki aturan yang logis.

- Kategori data ditentukan skalanya berdasarkan jumlah karaaktristik khusus yang dimilikinya.

- Perbedaan karakteristik yang sama tergambar dalam perbedaan yang sama dalam jumlah yang dikenakan pada kategori.

- Angka nol hanya menggambarkan satu titik dalam skala (tidak memiliki nilai nol absolut).

\section{Skala Rasio}

Skala rasio adalah skala pengukuran yang ditujukan pada hasil pengukuran yang bisa dibedakan, diurutkan, memiliki jarak tertentu, dan bisa dibandingkan. Skala rasio merupakan tingkatan skala paling tinggi dan paling lengkap dibanding skala-skala lainnya. Jarak atau interval antar tingkatan sudah jelas, dan memiliki nilai 0 (nol) yang mutlak. Nilai nol mutlak berarti benar-benar menyatakan tidak ada. Contoh Tabel.

\begin{tabular}{|c|c|c|}
\hline Data & Tinggi Badan & Berat Badan \\
\hline Nilda & 170 & 60 \\
\hline Mifta & 160 & 50 \\
\hline Janna & 150 & 40 \\
\hline
\end{tabular}

Skala pengukuran variabel penting untuk penentuan uji statistik yang sesuai: skala nominal dan ordinal hanya bisa menggunakan uji statistik non parametrik, sedangkan skala interval dan rasio bisa menggunakan statistik parametrik.

\section{STATISTIK PARAMETRIK DAN NONPARAMETRIK}

\section{A. Statistik Parametrik}

\section{Pengertian}

Statistik Parametrik, yaitu ilmu statistik yang mempertimbangkan jenis sebaran atau distribusi data, yaitu apakah data menyebar secara normal atau tidak. Statistik parametrik digunakan untuk menguji hipotesis dan variabel yang terukur. Dengan kata lain, data yang akan dianalisis menggunakan statistik parametrik harus memenuhi asumsi normalitas. 
Pada umumnya, jika data tidak menyebar normal, maka data seharusnya dikerjakan dengan metode statistik non-parametrik, atau setidak-tidaknya dilakukan transformasi terlebih dahulu agar data mengikuti sebaran normal, sehingga bisa dikerjakan dengan statistik parametrik.

Misal : "Berapa menit rata-rata waktu layanan pelanggan di restoran cepat saji X ?". Variabel waktu layanan pelanggan dapat diukur dalam menit.

2. Syarat-syarat statistik parametrik :

- Data dengan skala interval dan rasio

- Data menyebar/berdistribusi normal

3. Contoh metode statistik parametrik :

- Uji-z (1 atau 2 sampel)

- Uji-t (1 atau 2 sampel)

- Korelasi pearson,

- Perancangan percobaan (one or two-way anova parametrik), dll.

4. Keunggulan dan kelemahan statistik parametrik

$>$ Keunggulan

- Syarat syarat parameter dari suatu populasi yang menjadi sampel biasanya tidak diuji dan dianggap memenuhi syarat, pengukuran terhadap data dilakukan dengan kuat.

- Observasi bebas satu sama lain dan ditarik dari populasi yang berdistribusi normal serta memiliki varian yang homogen.

$>$ Kelemahan

- Populasi harus memiliki varian yang sama.

- Variabel-variabel yang diteliti harus dapat diukur setidaknya dalam skala interval.

- Dalam analisis varian ditambahkan persyaratan rata-rata dari populasi harus normal dan bervarian sama, dan harus merupakan kombinasi linear dari efek-efek yang ditimbulkan.

\section{B. Statistik Nonparametrik}

1. Pengertian

Statistik Non-Parametrik, yaitu statistik bebas sebaran (tidak mensyaratkan bentuk sebaran parameter populasi, baik normal atau tidak). Selain itu, statistik non-parametrik biasanya menggunakan skala pengukuran sosial, yakni nominal dan ordinal yang umumnya tidak berdistribusi normal.

Misal : "Berapa besar kepuasan pelanggan terhadap pelayanan restoran cepat saji X ?". variabel kepuasan tidak memiliki satandar pasti. 
2. Syarat statistik non-parametrik :

- Data tidak berdistribusi normal

- Umumnya data berskala nominal dan ordinal

- Umumnya dilakukan pada penelitian social

- Umumnya jumlah sampel kecil

3. Contoh metode statistik non-parametrik :

- Uji tanda (sign test)

- Rank sum test (wilcoxon)

- Rank correlation test (spearman)

- Fisher probability exact test

- Chi-square test, dll.

4. Keunggulan dan kelemahan statistik non-parametrik

$>$ Keunggulan :

- Tidak membutuhkan asumsi normalitas.

- Secara umum metode statistik non-parametrik lebih mudah dikerjakan dan lebih mudah dimengerti jika dibandingkan dengan statistik parametrik karena ststistika non-parametrik tidak membutuhkan perhitungan matematik yang rumit seperti halnya statistik parametrik.

- Statistik non-parametrik dapat digantikan data numerik (nominal) dengan jenjang (ordinal).

- Kadang-kadang pada statistik non-parametrik tidak dibutuhkan urutan atau jenjang secara formal karena sering dijumpai hasil pengamatan yang dinyatakan dalam data kualitatif.

- Pengujian hipotesis pada statistik non-parametrik dilakukan secara langsung pada pengamatan yang nyata.

- Walaupun pada statistik non-parametrik tidak terikat pada distribusi normal populasi, tetapi dapat digunakan pada populasi berdistribusi normal.

Kelemahan

- Statistik non-parametrik terkadang mengabaikan beberapa informasi tertentu.

- Hasil pengujian hipotesis dengan statistik non-parametrik tidak setajam statistik parametrik.

- Hasil statistik non-parametrik tidak dapat diekstrapolasikan ke populasi studi seperti pada statistik parametrik. Hal ini dikarenakan statistik nonparametrik mendekati eksperimen dengan sampel kecil dan umumnya membandingkan dua kelompok tertentu. 


\section{PERBEDAAN STATISTIK DESKRIPTIF DAN INFERENSIAL}

Statistik inferensial dan statistik deskriptif memiliki perbedaan yang sangat mendasar dalam proses analisis. Secara umum, kedua jenis statistik ini pun memiliki tujuan yang berbeda. Statistik deskriptif bertujuan untuk mendeskripsikan karakteristik data. Sedangkan statistik inferensial bertujuan untuk mengambil kesimpulan untuk populasi dengan menganalisis sampel.

Statistik deskriptif biasanya hanya disajikan dalam bentuk tabel dan grafik. Statistik uji yang digunakan pun terbilang sederhana seperti rata-rata, varians, dll. Sedangkan statistik inferensial, statistik yang digunakan sudah tergolong sangat rumit. Tidak semua orang mampu menggunakan statistik inferensial sehingga dibutuhkan keseriusan dan pembelajaran khusus sebelum menggunakannya. Karena itu, kita tidak bisa menggunakan apapun alat analisis yang ada pada analisis deskriptif untuk menyimpulkan data secara keseluruhan.

\section{KESIMPULAN}

Variabel Penelitian adalah suatu atribut, nilai atau sifat dari objek penelitian (individu atau kegiatan) yang memiliki variasi tertentu antara satu objek dengan objek lainnya. Skala pengukuran adalah sebuah acuan yang digunakan untuk menentukan panjang pendeknya interval yang ada dalam satuan alat ukur. Statistik Parametrik, yaitu ilmu statistik yang mempertimbangkan jenis sebaran atau distribusi data, yaitu apakah data menyebar secara normal atau tidak. Statistik Non-Parametrik, yaitu statistik bebas sebaran (tidak mensyaratkan bentuk sebaran parameter populasi, baik normal atau tidak). Statistik inferensial dan statistik deskriptif memiliki perbedaan yang sangat mendasar dalam proses analisisnya. Secara umum, kedua jenis statistik ini pun memiliki tujuan yang berbeda. Statistik deskriptif bertujuan untuk mendeskripsikan karakteristik data. Sedangkan statistik inferensial bertujuan untuk mengambil kesimpulan untuk populasi dengan menganalisis sampel.

\section{DAFTAR PUSTAKA}

1. Arsyam, M. (2020). MANAJEMEN PENDIDIKAN ISLAM..

2. Herianto, H. (2020). Teknik Menulis Artikel Konseptual.

3. Nazir, M. P. (2020). Metode Penelitian. Bogor: Ghalia Indonesia.

4. Herianto, H. (2020). Telaah Kurikulum 2013: Hasil Revisi Tahun 2018.

5. Purnomo. (2020). Bahan Ajar Variabel dan Hipotesis. Semarang : Poltekkes

6. Jusmiana, A., \& Herianto, H. (2020). Suplemen Materi Statistik Terapan dalam Ilmu Kesehatan.

7. Sapada, A.O. \& Arsyam, M. (2020) Ilmu Pengetahuan dan Teknologi Menurut Pandangan Islam.

8. Irianto, Agus. (2020) Statistik. Jakarta : Kencana 